\title{
Technological Activities and Antibiofilm Effect of Staphylococcus Equorum Isolated from Fermented Sausage
}

\author{
Ghada M. Khiralla \\ National Organization for Drug Control and Research (NODCAR), 6-7 AboHazem Street, Pyramids, PO Box \\ 29, Giza, Egypt \\ e-mail: gkhiralla@yahoo.com
}

Received: 9 November 2018; Accepted: 29 November 2018; Available online: 15 February 2019

\begin{abstract}
The present study aimed at evaluating the technological properties and the ability of Staphylococcus equorum to inhibit biofilm formation by Staphylococcus aureus and Escherichia coli O157:H7. Seventeen S. equorum strains were isolated from fermented sausage and examined for their ability to grow at 10 or $15^{\circ} \mathrm{C}$ in the presence of 10 or $15 \% \mathrm{NaCl}$ at $\mathrm{pH}$ values of $4.5,5.0$ or 5.5. Technological properties including catalases, superoxide dismutase, lipolytic and proteolytic activities of S. equorum strains were determined. All strains grew under the studied conditions and showed variable activities. The strain $S$. equorum HMA4 showed good characters of all the studied metabolic properties and had ability to grow under all studied conditions. The antagonistic effect of S. equorum HMA4 against $S$. aureus or $E$. coli $\mathrm{O} 157: \mathrm{H} 7$ biofilms was studied under the above conditions. There was a significant increasing in the reduction percentage of biofilm formation at $\mathrm{pH} 5.0$ and 5.5 comparing with those obtained at $\mathrm{pH} 4.5$. The antibiofilm effect of $S$. equorum HMA4 against $E$. coli $\mathrm{O} 157: \mathrm{H} 7$ was higher than its effect on biofilm of $S$. aureus. In conclusion, beside its role in the developing flavor and enhancing the color of the fermented foods, S. equorum HMA4 could be used as a protective starter against some foodborne pathogens in fermented foods.
\end{abstract}

Keywords: Biofilm; Protective starter; S. equorum; S. aureus and E. coli O157:H7.

\section{Introduction}

Microbial biofilms are defined as viable and nonviable microorganisms embedded in their polyanionic extracellular polymeric substances (EPS) that anchored to a biotic or abiotic surface [1,2]. Virtually all bacteria can grow as a biofilm [3]. Previous literatures indicated that approximately $80 \%$ of all bacterial infections either in human or animals are related to biofilms $[1,4,5]$. Antimicrobial biofilm resistance has become a global problem in the foodborne pathogens especially that grown on the surface of fermented foods [6-8]. Many strains of Shiga toxigenic Escherichia coli (STEC) are the reasons of foodborne disease, which recovered from meat products including the fermented sausages [9]. E. coli $\mathrm{O} 157: \mathrm{H} 7$ can grow in tryptone soy broth (TSB) containing 6.5\% $\mathrm{NaCl}$ or at a $\mathrm{pH}$ of 4.5 to 9.0 . Moreover, E. coli $\mathrm{O} 157: \mathrm{H} 7$ may represent a hazard in sausage batter, because when initially present at $10^{4} \mathrm{CFU} / \mathrm{g}$, this organism can survive fermentation, drying, and storage of fermented sausage regardless of whether an added starter culture was used [10]. The resistance of E. coli O157:H7 to $\mathrm{NaCl}$ concentration depends on the growth medium and temperature, where its growth at $37{ }^{\circ} \mathrm{C}$ was inhibited at $28 \%$ $\mathrm{NaCl}$ whereas at $10^{\circ} \mathrm{C}$, growth was inhibited at $24 \% \mathrm{NaCl}$ in TSB and at $26 \% \mathrm{NaCl}$ in poultry extract broth [11]. Moreover, $E$ coli $\mathrm{O} 157: \mathrm{H} 7$ has shown ability to attach to biotic and abiotic surfaces and to form biofilm [12]. $S$. aureus is able to grow in a wide range of temperatures $\left(7{ }^{\circ} \mathrm{C}\right.$ to $48.5^{\circ} \mathrm{C}$ with an optimum of 30 to $\left.37^{\circ} \mathrm{C}\right), \mathrm{pH}(4.2$ to 9.3 , with an optimum of 7 to 7.5 ) and $\mathrm{NaCl}$ concentrations (up to $15 \% \mathrm{NaCl}$ ). These features enable $S$. aureus to grow in a wide variety of foods including fermented sausage [13]. Therefore, the high prevalence of these pathogens that resist high $\mathrm{NaCl}$ concentrations and low $\mathrm{pH}$ values, may promote health risk to the consumer of the fermented meat products.

In fermented meat products, Micrococcaceae participate in the development and stability of a good red color through nitrate reductase activity that leads to the formation of nitrosomyoglobin [14]. Coagulase-negative staphylococci (CNS) are a heterogenous group of Gram-positive cocci including Staphylococcus xylosus, $S$. carnosus and S. equorum. It is well known that, S. equorum is responsible for developing flavor of fermented sausage by reduction of nitrate to nitrite and then to nitrous oxide, by preventing rancidity through peroxide decomposition, and by producing flavor and aroma compounds through proteolysis and lipolysis [15-20]. $S$. equorum represented $49 \%$ of staphylococcal isolates from French naturally fermented sausages [21]. 
Ten to forty percentage from southern Italian sausages [14] and 23.5\% from fresh sausages [22]. Due to its ability to grow at $10{ }^{\circ} \mathrm{C}, \mathrm{S}$. equorum has been suggested for the development of starter preparations for curing of meat products [16]. Moreover, S. equorum is known as a bacteriocin producer such as micrococcin P1 [18,23].

Besides its technological activities for developing flavor and enhancement the color of fermented meat, the current study aimed to determine the antibiofilm effect of $S$. equorum against $S$. aureus and E. coli O157:H7.

\section{Materials and methods}

\subsection{Isolation and identification of $S$. equorum}

S. equorum isolated from traditional fermented sausages from the local market of Giza City, Egypt was used in this study. The strains were isolated on Mannitol Salt Agar (MSA, Oxoid) after $48 \mathrm{~h}$ at $30{ }^{\circ} \mathrm{C}$ and identified as reported by Mauriello et al., [14]. Briefly, colonies from countable plates were initially tested for morphology, Gram-stain and catalase production. Gram-positive and catalase-positive cocci were purified by streaking on MSA. They were subjected to the oxidation/fermentation (OF) test in OF medium and to the anaerobic growth in semisolid thioglycollate medium [24]. Sensitivity to furazolidone, bacitracin and lysostaphin was determined as described by Kloos and Bannerman [25]. Production of pigment was observed on P-agar. Staphylococci were assayed for coagulase activity using the test tube with coagulase plasma (Becton, Dickinson \& Company, NJ, USA) and for novobiocin sensitivity. Other biochemical properties were studied using API Staph identification strips and API LAB Plus software according to the manufacturer's instructions (API, Biome'rieux System). Identification of the most potent strain was confirmed by partial sequencing of the 16S rRNA gene using fD1 (5'agagtttgatcctggctcag-3') and rD1 (5'-aaggaggtgatccagcc-3') (E. coli positions 8-17 and 1540-1524, respectively) primer [26]. The nucleotide sequence data obtained in the current work were submitted to the EMBL Nucleotide Sequence Database.

\subsection{Microbial growth}

The isolated $S$. equorum strains were tested for growth ability in yeast tryptone broth (YTB) at different temperatures $\left(10,15,20,30\right.$ and $\left.37^{\circ} \mathrm{C}\right)$. The effect of $\mathrm{pH}$ on the ability of growth was examined in YTB at $\mathrm{pH}$ values of 4.5, 5.0 and 5.5 (adjusted with $0.1 \mathrm{M} \mathrm{HCl}$ ) at temperatures usually used for meat fermentation (10 and $\left.15^{\circ} \mathrm{C}\right)$. The effect of $\mathrm{NaCl}$ concentrations $(10 \%$ and $15 \%)$ was also studied at 10 or $15^{\circ} \mathrm{C}$ [14]. Ten microlitres of an overnight culture of each strain were inoculated into the $250 \mathrm{~mL}$ of different media described above under static conditions for $48 \mathrm{~h}$. The growth response was followed by determining the optical density at $600 \mathrm{~nm}\left(\mathrm{OD}_{600}\right)$, and registered, whether positive or negative, after $48 \mathrm{~h}$.

\subsection{Technological properties}

\subsubsection{Catalase assay}

Catalase activity (CA) was measured on resting cells according to Aebi's method [14,19]. Results were expressed in arbitrary units (AU): $\mu$ mol of degraded $\mathrm{H}_{2} \mathrm{O}_{2} / \mathrm{min} / \mathrm{ml}$ of cells with $\mathrm{OD}_{600}=1.0$.

\subsubsection{Superoxide dismutase activity}

Superoxide dismutase (SOD) activity was determined by the method described by Mauriello et al [14]. Briefly, $2 \mathrm{~mL}$ overnight culture of the isolated strain was centrifuged at $13000 \mathrm{~g}$ for $5 \mathrm{~min}$. The cell pellet of each strain was washed once in $50 \mathrm{mM} \mathrm{K} \mathrm{HPO}_{4}, \mathrm{pH}$ 7.8. For SOD extraction $100 \mathrm{mg}$ cell pellet (wet weight) was suspended in $1 \mathrm{~mL}$ of the same buffer. Pellets were disrupted using glass beads $(\sim 0.1 \mathrm{~mm})$ on a vortex mixer for $5 \mathrm{~min}$. Afterwards, the mixture was centrifuged and the supernatant was used for determination of SOD activity. Ten $\mu \mathrm{L}$ of cell extract were added to $1.0 \mathrm{ml}$ of $150 \mu \mathrm{M}$ nitroblue tetrazolium (NBT), $10 \mathrm{mM}$ methionine, $1.2 \mu \mathrm{M}$ riboflavin, $50 \mathrm{mM} \mathrm{K} \mathrm{HPO}_{4} \mathrm{pH} 7.8$ and incubated at room temperature in a light chamber with a $60 \mathrm{~W}$ bulb lamp for $8 \mathrm{~min}$. Results were expressed as percentage $\mathrm{OD}_{560}$ according to the following equation: $\mathrm{SOD}$ activity $=(1-$ $\mathrm{S} / \mathrm{C}) \cdot 100$; where $\mathrm{S}$ is the $\mathrm{OD}_{560}$ of the sample and $\mathrm{C}$ is the $\mathrm{OD}_{560}$ of the control. Control is consisting of a solution without adding cell extract and incubated under the same conditions.

\subsubsection{Nitrate reductase assay}

Nitrate reductase (NR) activity was measured as described by Mauriello et al [14]. $2 \mathrm{~mL}$ overnight culture of the isolated strain was centrifuged at $13000 \mathrm{~g}$ for $5 \mathrm{~min}$. The cell pellet of each strain was resuspended in equal volume of $50 \mathrm{mM}$ phosphate buffer $\mathrm{pH} 7.0$. Yeast tryptone agar (YTA, tryptone $1 \%$, yeast extract $0.5 \%, \mathrm{NaCl}$ $0.4 \%$, agar $1.5 \%$, pH 7.0) plates supplemented with $\mathrm{KNO}_{3}(1 \mathrm{~g} / \mathrm{L})$ were prepared and wells were created using cork borers with $6 \mathrm{~mm}$ diameter. Thirty micrograms of the resuspended culture were loaded into wells. After incubation at $30^{\circ} \mathrm{C}$ for $7 \mathrm{~h}$ the plates were flooded with $1 \mathrm{~mL}$ of a $1: 1$ solution of NIT1 $(0.8 \mathrm{~g}$ sulphanilic acid in 
$100 \mathrm{~mL}$ of acetic acid $5 \mathrm{~N})$ and NIT2 (0.6 g N-N-dimethyl-1-Naphthylamine in $100 \mathrm{ml}$ of acetic acid $5 \mathrm{~N})$ for the detection of nitrite. The appearance of red haloes (expressed in $\mathrm{mm}$ ) surrounding the wells indicated the presence of nitrate reductase activity.

\subsubsection{Lipolytic activity}

Lipolytic activity (LA) was measured according to the method described by Mauriello et al [14]. Briefly, one $\mathrm{ml}$ of an overnight culture of each strain was inoculated into $10 \mathrm{ml}$ of a broth containing $1 \%$ tryptone, $0.5 \%$ yeast extract, $3 \% \mathrm{NaCl}, \mathrm{pH} 7.0$, supplemented with $4 \%(\mathrm{w} / \mathrm{v})$ beef fat. For the preparation of media, beef fat was homogenized by vigorous shaking. After incubation at $30^{\circ} \mathrm{C}$ for seven days, the samples were used for the determination of free fatty acids [14]. Lipolytic activity was expressed as a percentage of oleic acid.

\subsubsection{Proteolytic activity}

Proteolytic activity (PA) was measured according to the method described by Mauriello et al [14,19]. A clear zone surrounding the inoculated wells indicated proteolytic activity and its diameter was measured in mm.

\subsection{Anti-biofilm effect of $S$. equorum against foodborne pathogens}

Two foodborne pathogens; S. aureus and E coli O157:H7, were obtained from the culture collection of Food Science Department, Faculty of Agriculture, Ain Shams University. The antagonistic effect of S. equorum HMA4 against biofilm formation by the studied foodborne pathogens were tested by a colorimetric method adapted from previous work [27-29]. S. equorum and the tested pathogens were cultivated overnight at $37^{\circ} \mathrm{C}$ separately in $\mathrm{BHI}$ broths. After incubation, the three bacterial suspensions were washed with the saline solution, diluted in BHI (pH 7.4), and mixed in order to obtain the final suspension containing $5 \times 10^{7} \mathrm{CFU} / \mathrm{mL}$ of each tested pathogen. With each tested pathogen a quantity of $100 \mu \mathrm{L}$ of $S$. equorum were deposited per well in 96-well (Minitek, USA), that were incubated at tested temperatures $\left(10\right.$ or $\left.15^{\circ} \mathrm{C}\right)$. After $24 \mathrm{~h}$, the wells were washed twice with a saline solution $(\mathrm{NaCl} 0.9 \%)$, and then $100 \mu \mathrm{L}$ of crystal violet $(0.25 \%)$ were added in each well for biofilm colorization. After 10 min, wells were washed twice again with the saline solution and the remaining crystal violet was released by addition of $100 \mu \mathrm{L}$ of acetic acid (33\%).

The Optical density (OD) of each well was measured at $570 \mathrm{~nm}$ using a UV/Visible spectrophotometer (6105Jenway, U.K.). The positive control was the amount of biofilm formed by the pure culture of the tested pathogens, whereas the negative control was sterile BHI.

To study the anti-biofilm effect of $S$. equorum at different conditions including $\mathrm{NaCl}$ and $\mathrm{pH}$, the abovementioned experiment was carried out in the presence of 10 or $15 \% \mathrm{NaCl}$ at $\mathrm{pH} 4.5,5.0$ or 5.5.

Reduction percentage of biofilm formation was expressed using the following equation:

$\%$ Reduction $=\left[\left(\mathrm{OD}_{570}\right.\right.$ of tested pathogen $-\mathrm{OD}_{570}$ of tested pathogen and $S$. equorum $) / \mathrm{OD}_{570}$ of tested pathogen]x100.

\subsection{Statistical analysis}

The data obtained from three replicates were analyzed by a two-way ANOVA using 'Proc Mixed' (SAS 8.2, Cary, NC) for interaction effects of the strains, produce and sampling period. In all cases, the level of statistical significance was of $\mathrm{P}<0.05$.

\section{Results and discussion}

\subsection{Technological properties}

Seventeen Staphylococcus strains were isolated from sausage and identified as S. equorum according to the morphological and biochemical tests and API-Staph results. All isolated strains have grown well at temperature range of 10 to $37^{\circ} \mathrm{C}$ (data not shown). The ability of the isolated strains to grow at temperatures usually used for meat fermentation $\left(10\right.$ and $\left.15^{\circ} \mathrm{C}\right)$ at different $\mathrm{pH}$ values and $\mathrm{NaCl}$ concentrations was determined (Table 1). All isolated strains grew at $\mathrm{pH} 5.0$ and 5.5, however, at $\mathrm{pH} 4.5$ only 23.5 and $41.1 \%$ of the tested strains had ability to grow at 10 and $15^{\circ} \mathrm{C}$, respectively. On the other hand, all strains grew in the presence of $10 \% \mathrm{NaCl}$ at 10 and 15 ${ }^{\circ} \mathrm{C}$. Inhibitory effect on the ability of some $S$. equorum strains (47.1 and $29.4 \%$ at 10 and $15{ }^{\circ} \mathrm{C}$, respectively) was recorded when $15 \% \mathrm{NaCl}$ was added to the growth medium (Table 2).

These results indicated that not all $S$. equorum strains can grow under the main factors ( $\mathrm{pH}$ and salt stress) encountered during production of fermented meat. These results were in accordance with those reported by Sondergaard and Stahnke [20]. They found that increasing salt concentration from 5\% to $15 \% \mathrm{w} / \mathrm{v}$ decreased growth of S. carnosus, S. equorum and S. xylosus, but the effect of $\mathrm{pH}$ and temperature was much stronger than the effect of salt. Moreover, Carvalho et al., [30] stated that $S$. equorum showed to grow under all the studied conditions being more effective at $15^{\circ} \mathrm{C}, 20^{\circ} \mathrm{C}$ and $\mathrm{pH} 5.5$ at $20^{\circ} \mathrm{C}$, and $\mathrm{NaCl}$ concentration of $10 \%$; therefore, can 
be guaranteed their application in technological processes with varying temperatures. Recently, Lee et al., [17] demonstrated that, $S$. equorum KS1039 could be used as a potential starter culture for the fermentation of highsalt foods.

Table 1. Effect of $\mathrm{pH}$ on the growth ability of Staphylococcus equorum strains

\begin{tabular}{lllllll}
\hline \multirow{2}{*}{ Strains } & \multicolumn{3}{l}{ Growth at $10{ }^{\circ} \mathrm{C}$} & \multicolumn{5}{c}{ Growth at $15^{\circ} \mathrm{C}$} \\
\cline { 2 - 7 } & $\mathrm{pH} 4.5$ & $\mathrm{pH} 5.0$ & $\mathrm{pH} \mathrm{5.5}$ & $\mathrm{pH} \mathrm{4.5}$ & $\mathrm{pH} \mathrm{5.0}$ & $\mathrm{pH} \mathrm{5.5}$ \\
\hline HMA 1 & - & + & + & + & + & + \\
HMA 2 & - & + & + & - & + & + \\
HMA 3 & + & + & + & + & + & + \\
HMA 4 & + & + & + & + & + & + \\
HMA 5 & - & + & + & - & + & + \\
HMA 6 & - & + & + & - & + & + \\
HMA 7 & + & + & + & + & + & + \\
HMA 8 & - & + & + & - & + & + \\
HMA 9 & - & + & + & - & + & + \\
HMA 10 & - & + & + & + & + & + \\
HMA 11 & - & + & + & - & + & + \\
HMA 12 & - & + & + & - & + & + \\
HMA 13 & + & + & + & + & + & + \\
HMA 14 & - & + & + & - & + & + \\
HMA 15 & - & + & + & - & + & + \\
HMA 16 & - & + & + & - & + & + \\
HMA 17 & - & + & + & + & + & + \\
\hline
\end{tabular}

Table 2. Effect of $\mathrm{NaCl}$ concentration on the growth ability of Staphylococcus equorum strains

\begin{tabular}{lllll}
\hline \multirow{2}{*}{ Strains } & \multicolumn{3}{l}{ Growth at $10{ }^{\circ} \mathrm{C}$} & \multicolumn{3}{l}{ Growth at $15{ }^{\circ} \mathrm{C}$} \\
\cline { 2 - 5 } & $10 \% \mathrm{NaCl}$ & $15 \% \mathrm{NaCl}$ & $10 \% \mathrm{NaCl}$ & $15 \% \mathrm{NaCl}$ \\
\hline HMA 1 & + & - & + & - \\
HMA 2 & + & - & + & + \\
HMA 3 & + & + & + & + \\
HMA 4 & + & + & + & + \\
HMA 5 & + & - & + & + \\
HMA 6 & + & - & + & - \\
HMA 7 & + & - & + & + \\
HMA 8 & + & + & + & + \\
HMA 9 & + & + & + & + \\
HMA 10 & + & - & + & + \\
HMA 11 & + & + & + & + \\
HMA 12 & + & - & + & - \\
HMA 13 & + & + & + & + \\
HMA 14 & + & + & + & + \\
HMA 15 & + & + & + & - \\
HMA 16 & + & + & + & + \\
HMA 17 & + & - & + & - \\
\hline
\end{tabular}

The technological properties of the isolated strains, presented in Table 3, showed high variability amongst strains. All S. equorum strains had antioxidative enzymes catalase (5.3 - 19.6 AU) and SOD (2.5 - $43.5 \%$ activity). The strain S. equorum HMA4 displayed the highest values of catalase and SOD activities while the strains HMA2 and 16 had the lowest levels of catalase and SOD, respectively. About 52\% of the isolated strains showed ability to reduce nitrate (Table 3). Only 41.1 and $29.4 \%$ of the studied strains had lipolytic and proteolytic activity, respectively. In accordance with the obtained results, Carvalho et al., [30] stated that $42 \%$ and $30 \%$ of S. equorum and $S$. xylosus revealed lipolytic activity and proteolytic ability, respectively, while $65 \%$ of the strains reduced nitrate. In the present study, the $S$. equorum strains that showed proteoltic ability displayed greater proteolysis against myofibrillar than sarcoplasmic proteins. This result is in harmony with that reported by Mauriello et al [14].

In general, the strain S. equorum HMA4 showed good characters of all the studied metabolic properties and grew under all studied conditions. Therefore, this strain was subjected for further work to investigate its ability to inhibit biofilm formation by some foodborne pathogens. 
Table 3: Technological properties ${ }^{\mathrm{a}}$ of Staphylococcus equorum strains

\begin{tabular}{llllll}
\hline Strain & $\begin{array}{l}\text { Catalase activity }^{\mathrm{b}} \\
(\mathrm{AU})\end{array}$ & $\begin{array}{l}\text { SOD activity }^{\mathrm{c}} \\
(\%)\end{array}$ & $\begin{array}{l}\text { Nitrate reduction }^{\mathrm{d}} \\
(\mathrm{mm})\end{array}$ & $\begin{array}{l}\text { Lipolysis }^{\mathrm{e}} \\
(\%)\end{array}$ & $\begin{array}{l}\text { Proteolysis }^{\mathrm{f}} \\
(\mathrm{mm})\end{array}$ \\
\hline HMA 1 & $5.3 \pm 0.12$ & $14.2 \pm 0.22$ & $7 \pm 0.36$ & $7.05 \pm 0.25$ & $0 / 0$ \\
HMA 2 & $4.8 \pm 0.1$ & $11.3 \pm 0.42$ & $10 \pm 0.43$ & 0 & $9 / 0$ \\
HMA 3 & $16.3 \pm 0.31$ & $9.5 \pm 0.21$ & $12 \pm 0.51$ & 0 & $0 / 0$ \\
HMA 4 & $19.6 \pm 0.15$ & $43.5 \pm 1.63$ & $15 \pm 0.37$ & $35.2 \pm 0.12$ & $22 / 14$ \\
HMA 5 & $6.8 \pm 0.17$ & $12.3 \pm 0.19$ & 0 & 0 & $0 / 0$ \\
HMA 6 & $11.1 \pm 0.14$ & $15.4 \pm 0.31$ & $7 \pm 0.63$ & 0 & $2 / 2$ \\
HMA 7 & $19.1 \pm 0.13$ & $22.3 \pm 0.26$ & $10 \pm 0.52$ & 0 & $0 / 0$ \\
HMA 8 & $14.2 \pm 0.16$ & $14.6 \pm 0.34$ & 0 & $7.05 \pm 0.17$ & $0 / 0$ \\
HMA 9 & $13.4 \pm 0.22$ & $5.5 \pm 0.12$ & 0 & 0 & $12 / 2$ \\
HMA 10 & $12.0 \pm 0.21$ & $13.6 \pm 0.21$ & $8 \pm 0.24$ & 0 & $0 / 0$ \\
HMA 11 & $18.2 \pm 0.18$ & $5.9 \pm 0.125$ & 0 & $7.05 \pm 0.19$ & $0 / 0$ \\
HMA 12 & $5.4 \pm 0.12$ & $17.2 \pm 0.42$ & $11 \pm 0.51$ & 0 & $9 / 0$ \\
HMA 13 & $7.8 \pm 0.15$ & $16.2 \pm 0.22$ & 0 & $14.1 \pm 0.31$ & $0 / 0$ \\
HMA 14 & $12.3 \pm 0.31$ & $22.0 \pm 0.32$ & $10 \pm 0.35$ & 0 & $0 / 0$ \\
HMA 15 & $14.5 \pm 0.21$ & $6.8 \pm 0.33$ & 0 & $7.05 \pm 0.16$ & $0 / 0$ \\
HMA 16 & $12.1 \pm 0.23$ & $2.5 \pm 0.16$ & 0 & 0 & $0 / 0$ \\
HMA 17 & $16.2 \pm 0.26$ & $19.2 \pm 0.72$ & 0 & $7.05 \pm 0.14$ & $0 / 0$ \\
\hline
\end{tabular}

${ }^{a}$ Values are means of three replicates, standard deviations are always lower than $10 \%$ of means., ${ }^{b}$ Arbitrary units: $\mu \mathrm{moL}$ of degraded $\mathrm{H}_{2} \mathrm{O}_{2} / \mathrm{min} / \mathrm{mL}$ of cells with optical density at $600 \mathrm{~nm}\left(\mathrm{OD}_{600}\right)=1.0 .,{ }^{\mathrm{c}} \%$ of optical density, ${ }^{\mathrm{d}}$ Diameter of red haloes., e $\%$ of oleic acid., ${ }^{\mathrm{f}}$ Diameter of clear zone on myofibrillar/sarcoplasmic proteins.

\subsection{Anti-biofilm effect of $S$. equorum HMA4 against foodborne pathogens}

S. equorum HMA4 was tested for its ability to inhibit biofilm formation by S. aureus and E coli O157:H7 at 10 and $15^{\circ} \mathrm{C}$ in the presence of 10 or $15 \% \mathrm{NaCl}$ at $\mathrm{pH}$ values of $4.5,5.0$ or 5.5. Comparing with the biofilm formation of $S$. aureus, a significant reduction $(p \leq 0.05)$ in biofilm formation was detected when $S$. equorum HMA4 and $S$. aureus were synergistically incubated at both tested temperature $\left(10\right.$ and $\left.15{ }^{\circ} \mathrm{C}\right)(\mathrm{Fig} .1)$. In the presence of $10 \%$ $\mathrm{NaCl}$, the highest reduction effect $(30 \%)$ was obtained at $15{ }^{\circ} \mathrm{C}$ and $\mathrm{pH} 5.0$, whereas the highest reduction percentage in the presence of $15 \% \mathrm{NaCl}$ was $36 \%$ (Fig. 1).

The reduction percentage of biofilm formation was ranged from 5 to $24 \%$ and from 5 to $36 \%$ when $10 \%$ and $\mathrm{NaCl}$ was added to the incubation medium, respectively. There was significant increase in the reduction percentage of biofilm formation at pH 5.0 and 5.5 comparing with those obtained at pH 4.5 (Fig. 1). This may be due to the negative effect of low $\mathrm{pH}$ value $(\mathrm{pH} 4.5)$ on the growth of $S$. equorum, as shown in Table 1 . Same trend was obtained when E coli O157:H7 was used as tested strain (Fig.2). Remarkably, the highest reduction percentage of biofilm formation (34\%) was recorded when S. equorum and E coli O157:H7 were used together in the presence of $15 \% \mathrm{NaCl}$, however, there is no significant difference between reduction percentages at pH 5.0 and 5.5 (Fig. 2).
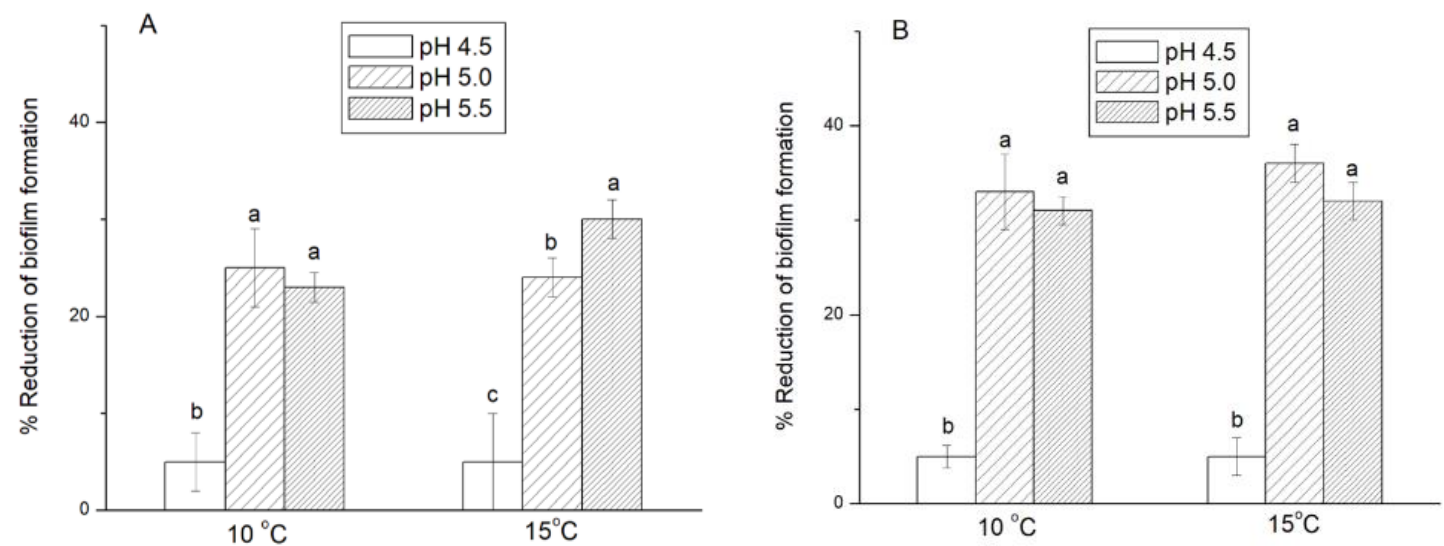

Fig. 1. Inhibitory effect of Staphylococcus equorum on biofilm formation by Staphylococcus aureus in the presence of $10 \%$ (A) and $15 \%$ (B) $\mathrm{NaCl}$ at 10 and $15^{\circ} \mathrm{C}$ at different $\mathrm{pH}$ values.

In general, the obtained inhibitory effect on the biofilm formation of both tested pathogens is probably due to the antagonistic behavior of the studied S. equorum strain HMA4. To the best of the author knowledge, the present work is the first study that considered the antagonistic effect of $S$. equorum against biofilm formation by foodborne pathogens such as S. aureus and E coli O157:H7. However, the effect of L. fermentum and L. paracasei against 
biofilm formation by another bacterial pathogen Pseudomonas aeruginosa was demonstrated at laboratory scale [27].
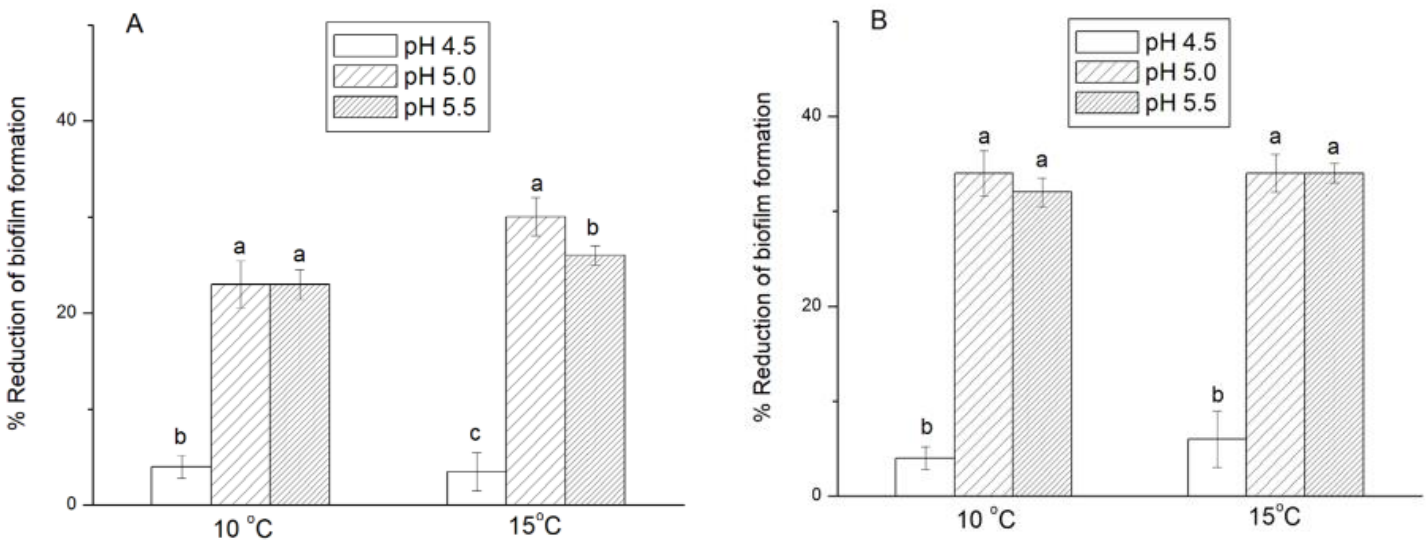

Fig. 2. Inhibitory effect of Staphylococcus equorum on biofilm formation by Escherichia. coli O157:H7 in the presence of $10 \%$ (A) and $15 \%$ (B) $\mathrm{NaCl}$ at 10 and $15^{\circ} \mathrm{C}$ at different $\mathrm{pH}$ values.

In conclusion, besides its role in the developing flavor and enhancing the color of the fermented foods, the obtained results demonstrated that $S$. equorum could be used as a protective starter against biofilm formation by some foodborne pathogens during fermentation of foods.

\section{References}

[1] Hall-Stoodley L, Stoodley P. Evolving concepts in biofilm infections. Cellular Microbiology. 2009;11(7):1034-1043.

[2] Homøe P, Bjarnsholt T, Wessman M, Sørensen HC, Johansen HK. Morphological evidence of biofilm formation in Greenlanders with chronic suppurative otitis media. European Archives of Oto-rhinolaryngology. 2009;266(10):1533-1538.

[3] Jacques M, Aragon V, Tremblay YD. Biofilm formation in bacterial pathogens of veterinary importance. Animal Health Research Reviews. 2010;11(2):97-121.

[4] Davies D. Understanding biofilm resistance to antibacterial agents. Nature Reviews Drug discovery. 2003;2(2):114-122.

[5] Raza A, Sarwar Y, Ali A, Jamil A, Haque A, Haque A. Effect of biofilm formation on the excretion of Salmonella enterica serovar Typhi in feces. International Journal of Infectious Diseases. 2011;15(11):e747e752.

[6] Balcázar JL, Subirats J, Borrego CM. The role of biofilms as environmental reservoirs of antibiotic resistance. Frontiers in Microbiology. 2015;6:1216.

[7] Marino A, Bellinghieri V, Nostro A, Miceli N, Taviano MF, Güvenç A, Bisignano G. In vitro effect of branch extracts of Juniperus species from Turkey on Staphylococcus aureus biofilm. FEMS Immunology \& Medical Microbiology. 2010;59(3):470-476.

[8] Büttner H, Mack D, Rohde H. Structural basis of Staphylococcus epidermidis biofilm formation: mechanisms and molecular interactions. Frontiers in Cellular and Infection Microbiology. 2015;5:14.

[9] Uyttendaele M, Vankeirsbilck S, Debevere J. Recovery of heat-stressed E. coli O157: H7 from ground beef and survival of E. coli O157: $\mathrm{H} 7$ in refrigerated and frozen ground beef and in fermented sausage kept at $7 \mathrm{C}$ and 22 C. Food Microbiology. 2001;18(5):511-519.

[10] Glass KA, Loeffelholz JM, Ford JP, Doyle MP. Fate of Escherichia coli O157: H7 as affected by pH or sodium chloride and in fermented, dry sausage. Applied and Environmental Microbiology. 1992;58(8):25132516.

[11] Conner DE. Temperature and $\mathrm{NaCl}$ Affect Growth and Survival of Escherichia coli 0157: H7 in PoultryBased and Laboratory Media. Journal of Food Science. 1992;57(2):532-533.

[12] Silagyi K, Kim SH, Lo YM, Wei CI. Production of biofilm and quorum sensing by Escherichia coli O157: $\mathrm{H} 7$ and its transfer from contact surfaces to meat, poultry, ready-to-eat deli, and produce products. Food Microbiology. 2009;26(5):514-519.

[13] Wakabayashi Y, Umeda K, Yonogi S, Nakamura H, Yamamoto K, Kumeda Y, Kawatsu K. Staphylococcal food poisoning caused by Staphylococcus argenteus harboring staphylococcal enterotoxin genes. International Journal of Food Microbiology. 2018;265:23-29. 
[14] Mauriello G, Casaburi A, Blaiotta G, Villani F. Isolation and technological properties of coagulase negative staphylococci from fermented sausages of Southern Italy. Meat Science. 2004;67(1):149-158.

[15] Casaburi A, Villani F, Toldrá F, Sanz Y. Protease and esterase activity of staphylococci. International Journal of Food Microbiology. 2006;112(3):223-229.

[16] Hammes WP, Hertel C. New developments in meat starter cultures. Meat Science. 1998;49:S125-38.

[17] Lee JH, Heo S, Jeong DW. Genomic insights into Staphylococcus equorum KS1039 as a potential starter culture for the fermentation of high-salt foods. BMC Genomics. 2018;19(1):136.

[18] Leroy S, Lebert I, Chacornac JP, Chavant P, Bernardi T, Talon R. Genetic diversity and biofilm formation of Staphylococcus equorum isolated from naturally fermented sausages and their manufacturing environment. International Journal of Food Microbiology. 2009;134(1-2):46-51.

[19] Dos Santos Cruxen CE, Funck GD, da Silva Dannenberg G, Haubert L, de Lima Marques J, Kroning IS, Chaves FC, da Silva WP, Fiorentini ÂM. Characterization of Staphylococcus xylosus LQ3 and its application in dried cured sausage. LWT-Food Science and Technology. 2017;86:538-543.

[20] Søndergaard AK, Stahnke LH. Growth and aroma production by Staphylococcus xylosus, S. carnosus and S. equorum - a comparative study in model systems. International Journal of Food Microbiology. 2002;75(12):99-109.

[21] Morot-Bizot SC, Leroy S, Talon R. Staphylococcal community of a small unit manufacturing traditional dry fermented sausages. International Journal of Food Microbiology. 2006;108(2):210-217.

[22] Rantsiou K, Iacumin L, Cantoni C, Comi G, Cocolin L. Ecology and characterization by molecular methods of Staphylococcus species isolated from fresh sausages. International Journal of Food Microbiology. 2005;97(3):277-284.

[23] Carnio MC, Höltzel A, Rudolf M, Henle T, Jung G, Scherer S. The macrocyclic peptide antibiotic micrococcin P1 is secreted by the food-borne bacterium Staphylococcus equorum WS 2733 and inhibits Listeria monocytogenes on soft cheese. Applied and Environmental Microbiology. 2000;66(6):2378-2384.

[24] Evans JB, Kloos WE. Use of shake cultures in a semisolid thioglycolate medium for differentiating staphylococci from micrococci. Applied Microbiology. 1972;23(2):326-331.

[25] Kloos WE, Bannerman TL. Staphylococcus and Micrococcus, Manual of Clinical Microbiology Washington, DC: American Society for Microbiology. 1995.

[26] Weisburg WG, Barns SM, Pelletier DA, Lane DJ. 16S ribosomal DNA amplification for phylogenetic study. Journal of bacteriology. 1991;173(2):697-703.

[27] Alexandre Y, Le Berre R, Barbier G, Le Blay G. Screening of Lactobacillus spp. for the prevention of Pseudomonas aeruginosa pulmonary infections. BMC Microbiology. 2014;14(1):107.

[28] Elhariry HM. Biofilm formation by endospore-forming bacilli on plastic surface under some food-related and environmental stress conditions. Global J Biotechnol Biochem. 2008;3:69-78.

[29] Elhariry HM. Attachment strength and biofilm forming ability of Bacillus cereus on green-leafy vegetables: cabbage and lettuce. Food Microbiology. 2011;28(7):1266-1274.

[30] Carvalho L, Fernandes MJ, Fernandes H, Semedo-Lemsaddek T, Elias M, Barreto AS, Fraqueza MJ. Selection of staphylococci strains isolated from a Portuguese traditional fermented/dry sausage for potential use as starter cultures. Options Mediterraneennes, 2012: 427-430.

(C) 2019 by the author(s). This work is licensed under a Creative Commons Attribution 4.0 International License (http://creativecommons.org/licenses/by/4.0/). Authors retain copyright of their work, with first publication rights granted to Tech Reviews Ltd. 